Jurnal Kajian Bimbingan dan Konseling

Vol 1, No. 2, 2016, hlm. 55-59

Tersedia Online di http://journal.um.ac.id/index.php/bk eISSN: 2503-3417

\title{
HUBUNGAN KETERAMPILAN KOMUNIKASI INTERPERSONAL DAN KEPERCAYAAN DIRI SISWA KELAS X SMAN 1 GARUM KABUPATEN BLITAR
}

\author{
Dinar Permadi Purnomo, Harmiyanto \\ Bimbingan dan Konseling-Fakultas Ilmu Pendidikan-Universitas Negeri Malang-Jl. Semarang No. 5 Malang \\ E-mail: dinarP74@gmail.com
}

\begin{abstract}
This study uses descriptive correlational study in order to describe and to know whether or not interpersonal communication skills affect students' self-confidence. The subject of the study includes the whole students of 10th grade at SMAN 1 Garum in the 2015/2016 academic year. The data analysis used in this study is descriptive analysis technique and Pearson product moment correlation. The result of the study shows that most of 10th grade students at SMAN 1 Garum of Blitar Regency have high level of interpersonal communication skills. In terms self-confidence, it is found that most of 10th grade students of SMAN 1 Garum of Blitar Regency also pose high level. The study suggests that there is significant correlation between interpersonal communication skills and self-confidence of 10th grade students at SMAN 1 Blitar of Blitar Regency. The result of the study shows that students with high level of communication skills also pose high level of selfconfidence.
\end{abstract}

Keywords: interpersonal communication skills; self-confidence; senior high school

\begin{abstract}
Abstrak: Penelitian ini bertujuan untuk menggambarkan dan mengetahui ada tidaknya hubungan antara keterampilan komunikasi interpersonal dan kepercayaan diri siswa. Penelitian menggunakan rancangan deskriptif korelasional. Hasil penelitian menunjukkan sebagian besar siswa kelas X SMAN 1 Garum Kabupaten Blitar yang memiliki keterampilan komunikasi interpersonal tinggi. Sebagian besar siswa kelas X SMAN 1 Garum Kabupaten Blitar yang memiliki kepercayaan diri tinggi. Terdapat hubungan yang signifikan antara keterampilan komunikasi interpersonal dengan kepercayaan diri siswa kelas X di SMAN 1 Garum Kabupaten Blitar. Hal ini membuktikan bahwa siswa yang memiliki keterampilan komunikasi tinggi maka rasa kepercayaan dirinya tinggi.
\end{abstract}

Kata kunci: keterampilan komunikasi interpersonal; kepercayaan diri; sekolah menengah atas

Tugas-tugas perkembangan remaja adalah mencapai hubungan baru dan yang lebih matang dengan teman sebaya baik pria maupun wanita. Mencapai peran sosial pria dan wanita, menerima keadaan fisiknya dan menggunakan tubuhnya secara efektif. Mengharapkan dan mencapai perilaku sosial yang bertanggung jawab, mencapai kemandirian emosional dari orang tua dan orang-orang dewasa lainnya. Mempersiapkan karir ekonomi, perkawinan dan keluarga serta memperoleh perangkat nilai dan sistem etis sebagai pegangan untuk berperilaku mengembangkan ideologi (Hurlock, 2009:209). Salah satu tugas perkembangan masa remaja adalah mencapai hubungan baru dan yang lebih matang dengan teman sebaya baik pria maupun wanita. Untuk memenuhi tugas perkembangan tersebut, terdapat beberapa kesulitan salah satunya adalah melakukan komunikasi dengan orang lain (menyampaikan pikiran, pendapat, dan perasaannya). Kesulitan komunikasi ini dapat terjadi di lingkungan keluarga, sekolah, maupun masyarakat. Salah satu yang mempengaruhi komunikasi interpersonal remaja adalah rasa percaya diri. Siswa dengan percaya diri yang tinggi akan 
yakin dengan kemampuannya untuk mencapai tujuan, kompetensi akademik, dan hubungan dengan orangtua dan teman sebaya (Lal, 2014:189).

SMA Negeri 1 Garum merupakan salah satu institusi pendidikan yang siswanya adalah usia remaja. Dimana siswa tersebut tidak terlepas dari masalah komunikasi, baik komunikasi dalam proses belajar mengajar maupun interaksi dengan teman sebaya. SMA Negeri 1 Garum memiliki jumlah sekitar 900 siswa, dengan karakter, kemampuan komunikasi interpersonal dan tingkat kepercayaan diri yang berbeda-beda. Hasil observasi ditemukan seorang siswa yang kurang percaya diri untuk berinteraksi dengan teman, terutama dengan teman lawan jenis. Dia merasa cemas, takut temannya tersebut memberikan tanggapan yang negatif. Hal ini menyebabkan interaksinya dengan teman menjadi terhambat dan sulit untuk berbicara secara langsung dengan teman yang dituju. Hal lain yang ditemukan dalam observasi adalah adanya siswa yang berkelahi hanya karena salah dalam menerima komunikasi dari teman. Guyonan dari teman dianggapnya sebagai sesuatu hal yang serius dan membuat marah.

Keterampilan komunikasi interpersonal (interpersonal communication skill) berhubungan dengan komunikasi antar orang, biasanya face to face dalam setting pribadi (Hardjana, 2003:85). Keterampilan komunikasi interpersonal adalah keterampilan komunikasi antara orang-orang secara tatap muka, memungkinkan setiap pesertanya menangkap reaksi orang lain secara langsung, baik secara verbal ataupun non-verbal sehingga dapat terjadi saling pengertian dan empati satu dengan lainnya (Noberta, 2011:19). Keterampilan komunikasi interpersonal juga dapat diartikan sebagai kemampuan berinteraksi secara verbal dan nonverbal yang dimiliki individu secara khas yang digunakan untuk menyampaikan informasi kepada orang lain dengan tujuan untuk memperoleh salah pemahaman dan saling pengertian antara pemberi informasi dan penerima informasi (Dahnia, 2010:15). Menurut Widjaja (dalam Rasuly, 2012:38) ada beberapa keterampilan dasar yang terdapat dalam keterampilan komunikasi interpersonal, yaitu (1) keterampilan menyampaikan, (2) keterampilan menerima, dan (3) keterampilan dalam menangkap pesan-pesan non verbal.

Kepercayaan diri berarti mengapresiasi dan menilai diri sendiri. Lebih tepatnya memiliki sikap positif dan keyakinan dari diri kita sendiri-kita mengendalikan hidup kita dan kita dapat melakukan segala sesuatu yang kita ingin (Radu, 2014:62). Rasa percaya diri didasarkan pada kepercayaan yang realistis terhadap kemampuan yang dimiliki oleh individu. Bila individu merasa rendah diri, individu tidak berhasil menyadari kemampuan yang sebenarnya dimiliki (Page \& Cindy, 2002:146). Lindenfield (1997:4-11) menjelaskan bahwa ada dua jenis rasa percaya diri yaitu: rasa percaya diri lahir dan rasa percaya diri batin. Percaya diri lahir memungkinkan individu untuk tampil berperilaku dengan cara menunjukkan kepada dunia luar bahwa individu tersebut yakin akan dirinya. Ciri utama orang memiliki kepercayaan diri lahir menurut Lindenfield ada empat, yakni (1) komunikasi; (2) ketegasan; (3) penampilan diri; (4) pengendalian perasaan. Percaya diri batin adalah percaya diri yang memberi seseorang perasaan dan anggapan bahwa kita dalam keadaan baik. Kepercayaan diri batin dimiliki oleh orang yang memiliki ciri (1) cinta diri; (2) pemahaman diri; (3) tujuan yang jelas; dan (4) berpikir positif.

DeVito (1997, dalam Nastiti 2011:71) berpendapat bahwa dalam komunikasi interpersonal terdapat aspek-aspek keterbukaan, empati, perasaan positif, dan kesetaraan, dimana aspek-aspek tersebut berpengaruh dalam pembentukan rasa percaya diri. Aspek lainnya yang juga berpengaruh terhadap kepercayaan diri adalah dukungan. Dukungan yang dapat mempengaruhi kepercayaan diri remaja adalah dukungan yang diberikan secara verbal, yaitu dengan komunikasi, maupun secara non-verbal, yaitu dengan memfasilitasi kebutuhan remaja (Nastiti, 2011:71). Adanya dukungan dari lingkungan sekitar, terutama keluarga, akan menghindarkan remaja dari kemungkinan kurang rasa percaya diri (lack of self confidence).

Berdasarkan latar belakang tersebut, masalah yang dibahas dalam penelitian ini adalah; (1) bagaimana gambaran keterampilan komunikasi interpersonal siswa kelas X di SMAN 1 Garum, (2) bagaimana gambaran kepercayaan diri siswa kelas X di SMAN 1 Garum, (3) apakah ada hubungan antara keterampilan komunikasi interpersonal dan kepercayaan diri siswa kelas X di SMAN 1 Garum. 
Purnomo, Harmiyanto, Pengembangan Model Pelatihan... | 57

\section{METODE}

Penelitian ini dilakukan di SMAN 1 Garum Kabupaten Blitar. Populasi dari penelitian ini didasarkan pada pertimbangan bahwa SMA telah memasuki usia remaja yang perlu memiliki rasa percaya diri untuk bisa berkomunikasi dengan baik dan diterima oleh lingkungannya. Pertimbangan selanjutnya adalah dimana siswa-siswi kelas X mulai melakukan penyesuaian dengan lingkungan sekolah barunya sehingga membutuhkan komunikasi yang baik. Jumlah populasi sebanyak 385 siswa yang terbagi ke dalam lima kelas IPA dan lima kelas IPS. Penelitian ini menggunakan teknik random sampling, dimana untuk mendapatkan sampel yang langsung dilakukan pada unit sampling (Fauzi, 2009:187). Dalam teknik ini peneliti mengambil sampel kelas dimana kelas yang dijadikan sampel adalah 2 kelas IPA dan 2 kelas IPS

Penelitian ini tergolong penelitian deskriptif dan korelasional. Penelitian deskriptif bertujuan untuk menggambarkan keadaan atau status fenomena. Penelitian korelasional bertujuan untuk menemukan ada tidaknya hubungan dua fenomena atau lebih (Arikunto, 2006:270).

Pengumpulan data dalam penelitian ini dilakukan dengan membagikan kuesioner. Kuesioner yang dilancarkan adalah kuesioner yang telah dilakukan uji validitas dan reliabilitas. Analisis data yang digunakan dalam penelitian ini adalah analisis statistik deskriptif dan analisis korelasi. Analisis statistik deskriptif digunakan untuk mendeskripsikan tentang keterampilan komunikasi interpersonal dan kepercayaan diri siswa serta sub variabel dari setiap variabel. Analisis korelasi digunakan untuk menguji hipotesis adanya hubungan antara keterampilan komunikasi interpersonal dan kepercayaan diri siswa. Peneliti menggunakan program SPSS 20 for windows untuk memudahkan dalam menganalisis. Hasil korelasi jika nilai signifikansi kurang dari atau sama dengan 0,05 maka dapat dikatakan signifikan. Sebaliknya jika signifikansi lebih dari 0,05 maka dapat dikatakan tidak signifikan.

\section{HASIL}

Terdapat 66\% siswa kelas X SMAN 1 Garum Kabupaten Blitar yang memiliki keterampilan komunikasi interpersonal yang tinggi. Siswa yang memiliki keterampilan komunikasi sedang sebanyak $34 \%$, sedangkan siswa yang memiliki keterampilan komunikasi rendah tidak ada. Terdapat 78\% siswa kelas X SMAN 1 Garum Kabupaten Blitar memiliki kepercayaan diri tinggi. Siswa yang memiliki kepercayaan diri sedang sebanyak $22 \%$ siswa, sedangkan untuk siswa yang memiliki kepercayaan diri rendah tidak ada. Berdasarkan analisis korelasi dapat diketahui $r$ hitung $(0,164)$ lebih besar daripada $r$ tabel $(0,156)$. Dapat disimpulkan $\mathrm{H}_{1}$ diterima dan $\mathrm{H}_{0}$ ditolak, yang artinya telah terbukti bahwa terdapat hubungan yang signifikan antara keterampilan komunikasi interpersonal dengan kepercayaan diri siswa yang mengikuti ekstrakurikuler di SMAN 1 Garum kabupaten Blitar.

Siswa yang memiliki keterampilan komunikasi interpersonal tinggi menurut Widjaja (dalam Dahnia, 2010:17) memiliki banyak manfaat, yaitu (1) mengenal diri dan orang lain; (2) mengetahui dunia luar; (3) menciptakan dan memelihara hubungan; (4) mengubah sikap dan perilaku; (5) bermain dan mencari hiburan; dan (6) membantu orang lain. Manfaat yang pertama adalah mengenal diri dan orang lain. komunikasi interpersonal memberikan kesempatan untuk membicarakan diri dengan orang lain sehingga mendapat perspektif baru tentang diri sendiri, dan memahami lebih dalam tentang sikap dan perilaku.

Siswa yang memiliki keterampilan komunikasi interpersonal yang tinggi maka akan dapat: (1) mengenal diri dan orang lain; (2) mengetahui dunia luar; (3) menciptakan dan memelihara hubungan; (4) mengubah sikap dan perilaku; (5) bermain dan mencari hiburan; dan (6) membantu orang lain. Manfaat yang pertama adalah mengenal diri dan orang lain. Komunikasi interpersonal memberikan kesempatan untuk membicarakan diri dengan orang lain sehingga mendapat perspektif baru tentang diri sendiri, dan memahami lebih dalam tentang sikap dan perilaku. Sebaliknya siswa yang kurang memiliki keterampilan komunikasi interpersonal maka akan sulit dalam berhubungan dengan masyarakat dan lingkungan sekitar.

Siswa yang memiliki kepercayaan diri tinggi maka memiliki pandangan yang realistis tentang diri mereka sendiri dan kemampuan mereka, sehingga membuat mereka tekun dalam berusaha. Mereka yang memiliki kepercayaan diri tinggi akan mudah dikenal dan mengenal orang lain, karena dengan rasa kepercayaan diri 
akan lebih mudah dalam bergaul dengan lingkungan. Sebaliknya jika memiliki kepercayaan diri yang rendah dapat mengurangi kekuatan, merasa tidak berdaya, dan akhirnya memiliki pandangan negatif terhadap diri sendiri. Kurangnya kepercayaan diri dalam diri individu, juga akan membuat individu tersebut dikuasai oleh rasa rendah diri dalam kehidupannya, dan ia akan tumbuh menjadi pribadi yang pesimis. Selain itu, siswa yang memiliki kepercayaan diri yang rendah dapat berdampak pada nilai prestasi yang rendah dan cenderung menutup diri dari lingkungan (Wiharani, 2014:12).

Keterampilan komunikasi interpersonal dan kepercayaan diri memiliki hubungan yang signifikan. Siswa yang memiliki keterampilan komunikasi interpersonal tinggi maka kepercayaan diri siswa tersebut juga tinggi. Begitu pula sebaliknya, jika kepercayaan diri tinggi maka keterampilan komunikasi interpersonal tinggi.

\section{BAHASAN}

Berdasarkan hasil penelitian, terdapat 66\% siswa yang memiliki keterampilan komunikasi interpersonal tinggi, dan sebanyak 34\% siswa memiliki keterampilan komunikasi interpersonal yang sedang. Oleh karena itu dapat disimpulkan bahwa sebagian besar siswa kelas X SMA Negeri 1 Garum memiliki tingkat keterampilan komunikasi interpersonal yang tinggi. Siswa dengan keterampilan komunikasi interpersonal yang tinggi mudah dalam menyampaikan, menerima dan menangkap pesan-pesan, baik pesan verbal maupun non-verbal. Dengan keterampilan komunikasi interpersonal yang mereka miliki, mereka tidak mendapat kesulitan untuk mengungkapkan pikiran perasaan, ide, dan gagasan kepada orang lain. Selain itu siswa juga cenderung mampu untuk menyampaikan pesan agar mudah dipahami oleh lawan komunikasi.

Perbedaan tingkat keterampilan komunikasi interpersonal antara siswa satu dengan siswa lainnya dipengaruhi oleh beberapa aspek, yaitu kepercayaan, keterbukaan, empati, perilaku sportif, dukungan, kepositifan, dan kerjasama (Rahmat, 2005: 129 \& De Vito, 1997: 290). Kepercayaan dan keterbukaan sangat berpengaruh dalam proses komunikasi. Jika individu dapat mempercayai lawan komunikasinya, maka individu tersebut cenderung akan terbuka dan jelas dalam menyampaikan pesan dan tanggapan terhadap lawan komunikasinya. Empati dan perilaku sportif dapat mempengaruhi keterampilan komunikasi interpersonal. Perilaku yang sportif akan mendorong individu untuk menerima, jujur, dan berempati terhadap lawan komunikasinya. Individu yang mampu berperilaku sportif dan memiliki empati akan lebih mudah dalam berkomunikasi dengan teman, guru, orangtua, dan lingkungan sekitarnya.

Hasil analisis deskripsi data penelitian menunjukan siswa yang memiliki kepercayaan diri yang tinggi sebanyak $78 \%$, siswa yang memiliki kepercayaan diri sedang sebanyak $22 \%$, dan tidak ada siswa yang memiliki kepercayaan diri rendah. Oleh karena itu dapat disimpulkan bahwa sebagian besar siswa kelas X SMA Negeri 1 Garum memiliki tingkat kepercayaan diri yang tinggi, yang berarti para siswa memiliki keyakinan terhadap kemampuan atau potensi yang dimilikinya, dan merasa nyaman dengan dirinya sendiri.

Adanya perbedaan tingkat kepercayaan diri antara siswa satu dengan siswa lainnya dipengaruhi oleh faktor pembentuk kepercayaan diri, yaitu pola asuh, sekolah, teman sebaya, masyarakat, dan pengalaman. Pola asuh yang diterapkan orangtua kepada anak, yang menerima dan memberi perhatian serta kasih sayang yang tulus akan membuat anak menjadi individu yang mampu melihat hal-hal positif pada dirinya. Sama halnya dengan faktor sekolah, guru yang memberikan perhatian dan penerimaan akan mendorong siswa untuk merasa bahwa dirinya berharga. Bagi remaja, teman sebaya merupakan pihak yang penting dalam kehidupan mereka. Individu yang memiliki banyak teman sebaya akan merasa diterima, dan dapat mengembangkan kepercayaan dirinya dengan baik. Individu yang ditolak oleh kelompok teman sebayanya akan merasa tidak berharga dan rendah diri, karena tidak memiliki teman. Hal ini yang membuat penerimaan teman sebaya menjadi sangat berpengaruh terhadap pembentukan kepercayaan diri.

Keterampilan komunikasi interpersonal saling berhubungan dengan kepercayaan diri. Jika siswa memiliki keterampilan interpersonal yang baik, maka kepercayaan diri siswa akan tinggi. Semakin baik keterampilan komunikasi interpersonal siswa, akan semakin tinggi pula kepercayaan diri siswa tersebut. Siswa yang kurang percaya diri akan cenderung sedapat mungkin untuk menghindari situasi komunikasi (Rahmat, 2005:109). Keterampilan komunikasi interpersonal termasuk dalam ciri-ciri individu yang memiliki kepercayaan diri lahir. Keterampilan komunikasi interpersonal sebagai salah satu cara individu untuk menunjukkan pada 
dunia luar bahwa dia yakin dengan dirinya sendiri. Keterbukaan, empati, perilaku sportif, dukungan, kepositifan ti-dak akan didapatkan oleh remaja yang kurang percaya diri, karena hal-hal tersebut hanya dapat dipelajari dengan cara berkomunikasi dengan orang lain. melalui keterampilan komunikasi interpersonal dalam lingkungan keluarga, sekolah, teman sebaya, dan masyarakat dapat membentuk kepercayaan diri remaja. Jika lingkungan keluarga, sekolah, teman sebaya, dan masyarakat dapat melatih keterampilan komunikasi interpersonal yang dapat dipercaya, terbuka, berempati, sportif, mendukung, dan positif kepada remaja, maka secara tidak langsung akan membentuk kepercayaan diri remaja tersebut.

\section{SIMPULAN DAN SARAN}

\section{Simpulan}

Kesimpulan penelitian ini adalah sebagian besar siswa kelas X SMAN Negeri 1 Garum Kabupaten Blitar memiliki keterampilan komunikasi interpersonal. Sebagian besar siswa kelas X SMAN Negeri 1 Garum Kabupaten Blitar memiliki kepercayaan diri yang tinggi. Terdapat hubungan yang signifikan antara keterampilan komunikasi interpersonal dengan kepercayaan diri siswa kelas X SMAN Negeri 1 Garum Kabupaten Blitar.

\section{Saran}

Bagi konselor, dapat menjadi bahan dalam memberikan layanan dasar bidang pribadi sosial yang bersifat pengembangan keterampilan komunikasi interpersonal dan kepercayaan diri siswa. Bagi peneliti selanjutnya, dapat menjadi sumber bacaan mengenai hubungan keterampilan komunikasi interpersonal dan kepercayaan diri siswa.

\section{DAFTAR RUJUKAN}

Arikunto, S. 2006. Prosedur Penelitian: Suatu Pendekatan Praktek. Jakarta: Rineka Cipta

Dahnia, L. 2010. Hubungan Antara Kemampuan Bilingual dengan Keterampilan Komunikasi Interpersonal pada Siswa Kelas X SMAN 4 Malang. Skripsi tidak diterbitkan. Malang: Fakultas Ilmu Pendidikan UM.

DeVito, Joseph. 2011. Komunikasi Antar Manusia. Edisi Kelima. Jakarta: Profesional Books. Fauzi, Muchamad. 2009. Metode Penelitian Kuantitatif Sebuah Pengantar. Semarang: Walisongo Press. Hardjana, A M. 2003. Komunikasi Intrapersonal dan Interpersonal. Yogyakarta: Kanisius.

Hurlock, E.B. 2009. Psikologi Perkembangan Suatu Pendekatan Sepanjang Rentang Kehidupan. Jakarta: Erlangga

Lal, Krishan. 2014. Emotional Marturity, Self Confidence and Academic Achievement of Adolencents in Relation to Their Gender and Urban-Rural Background. American International Jorunal of Research in Humanties, Arts, and Social Sciences, (online), 5 (2): 188-193, (http://www.iasir.net diakses 20 Mei 2015).

Lindenfield, Gael. 1997. Mendidik Anak Agar Percaya Diri. Jakarta: Arcan.

Nastiti, Anindita Woro. 2011. Hubungan Antara Komunikasi Interpersonal dengan Kepercayaan Diri Remaja Pada Siswa SMPN 5 Malang. Skripsi tidak diterbitkan. Malang: Fakultas Ilmu Pendidikan UM.

Norberta, Dian Prima. 2011. Pengembangan Inventori Keterampilan Komunikasi Interpersonal Berbasis WEB Bagi Siswa SMA. Skripsi tidak diterbitkan. Malang: Fakultas Ilmu Pendidikan UM.

Page, A., \& Cindy. 2002. Kiat Meningkatkan Harga Diri Anda. Jakarta: Archan.

Radu, Ababei. 2014. Study Of Differences Concerning Decision Making And Self-Confidence Among The Students Of Vasile Alecsandri University Of Bacau. Scientific Journal of Education, Sports, and Health, (online), 15 (1): 6171, (http://web.a.ebscohost.com/ehost/pdfviewer diakses 11 Mei 2015).

Rakhmat, Jalaludin. 2005. Psikologi Komunikasi, Edisi Revisi. Bandung: Remaja Rosdakarya.

Rasuly, Maulidir. 2012. Hubungan Antara Tingkat Kepercayaan Diri dan Penerimaan Diri Dengan Keterampilan Komunikasi Interpersonal Siswa Kelas XI SMK Negeri se-Kota Pamekasan. Skripsi tidak diterbitkan. Malang: Fakultas Ilmu Pendidikan UM. 